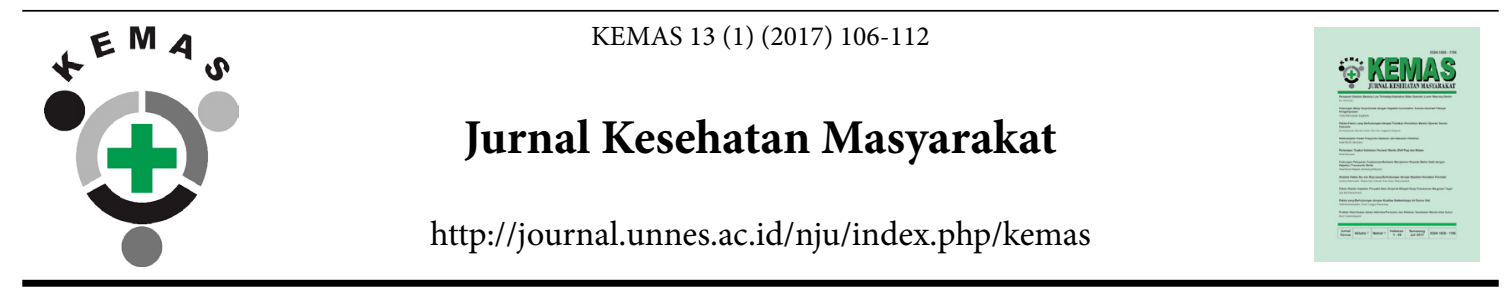

\title{
THE POSITIVE DEVIANCE OF FEEDING PRACTICES AND CARRING WITH NUTRITIONAL STATUS OF TODDLER AMONG POOR FAMILIES
}

\author{
Merita $^{\bowtie}$, Mila Triana Sari, Hesty \\ Stikes Baiturrahim Jambi
}

\section{Info Artikel}

Article History:

Submitted December 2016

Accepted July 2017

Published July 2017

Keywords:

Positive Deviance; Nutri-

tional Status; Toddler; Poor

\section{DOI}

http://dx.doi.org/10.15294/

kemas.v13i1.7919

\begin{abstract}
There are poor families with income less than minimum wage (IDR 1,900,000 / month) In Baru Village, Sarolangun Jambi. However, in reality the majority of toddler in the village have a relatively good nutritional status. The purpose of this study was to know the positive deviance of feeding practices and carring with nutritional status of toddler among poor families. This study used a cross-sectional study design. This research was conducted on April until August, 2016 in Village's Baru, Sarolangun, Jambi. The sampling technique in this study was total sampling. The samples was 84 under five age children from poor families. Determination of nutritional status using indicators of Weight for Age, which refers to the standard Kemenkes RI. The data of positive deviance taken using a questionnaire tools. The data collected was analyzed by univariate and bivariat test(chisquare test). The results showed that the positive deviance of infant feeding practice habits $(91,7 \%)$, toddler's care $(85,7 \%)$, nutritional status of toddler $(90,5 \%)$ categorized was good. The conclusion, the are relationship between positive deviance of feeding practices and carring with nutritional status of toddler among poor families $(\mathrm{p}<0,05)$.
\end{abstract}

\section{Introduction}

Toddler phase is known as the golden age since this period will determine the further growth and development of children. Thus, the nutritional status of children is one indicator to determine the level of public health. Nutrition is one of the most important factors affecting the individual or society. Malnutrition can propose a negative impact on the physical and mental growth, which in turn will hamper the achievement of learning. Another result is a decrease in immunity, cause loss of healthy life span of a toddler, as well as more serious impact such as disability, high morbidity and also mortality acceleration (Ali, 2006; Mamhidira 2006; Andriani, 2012).
Malnutrition is commonly assumed only due to poverty, but data from studies in various countries expressed except in a case of starvation, food availability is not the only cause (World Bank, 2006). Malnutrition can be influenced by other factors such as the mother's knowledge (Rayhan, 2006), parenting method (Lutter, 2011), access to health services (Mosquera, 2012), water and sanitation (Mashal, 2008). It will be worse by lack of knowledge of nutrition and lack of effort in applying that knowledge in everyday life (Khomsan, 2014).

Based on UNICEF framework that has been adapted to Indonesia's conditions, causes of nutritional problems consist of the direct cause, indirect cause, root of the problem, 
and the subject matter. The direct causes are children's food consumption and infectious diseases that may be suffered by the child. The cause of malnutrition is not only due to the lack of food but also infectious diseases. Children who eat well but have frequent diarrhea or fever can suffer from malnutrition. As for the indirect causes, food safety within the family, parenting, health care, and environmental health, are the examples. These factors strongly associated with the level of education, knowledge, and skills of the family. Parenting can affect the child's food intake and infectious diseases that may be suffered by a toddler.

Interesting event was found in slums and poor areas, that is a presence of toddler with good nutritional status. It is a form of positive deviance that was successfully applied by mothers in childcare. Parents, in addition to acting as caregivers and educators of children in the family, also play an important role in influencing the growth and development of children because parents are more familiar with them.

The researchers observed that despite the poverty in the community, some poor families had nourished children. Positive deviance or a community-based approach to development (Pascale, 2010). The Positive Deviance Initiative based on the belief that problem-solving abilities in principle exist within the society itself (Leavy, 2011).

Studies from various countries concluded that PD significantly associated with the growth of children (Sripaipan, 2002), exclusive breastfeeding (Dearden, 2002), the nutritional status of children (Pryer, 2004), a decrease in infant mortality (Mackintosh, 2002; Bolles, 2012), and a child's upbringing (Parvanta, 2007). In Indonesia, studies about PD have been conducted in several areas of poor families. The results of several studies suggest that PD would significantly affect the nutritional status of children under the age of two in Dairi, North Sumatra (Turnip, 2014).

We conclude that, based on the results of observation, in the Baru Village, Sarolangun Jambi there are poor families with incomes of less than the minimum wage (IDR. 1,900,000 / month). However, in reality the majority of young children in the village had a picture of a relatively good nutritional status. It is inseparable from the role of parents in feeding and parenting a toddler. Parental feeding behaviors can be interpreted also as an activity of a parent to meet the dietary, health and safety, helping to develop and maintain good eating behaviors, and promote a pleasant dining environment. Meanwhile, According to Lubis (2008), the mother as the central figure and is essential to implement life, especially in infants. Children still need the guidance of a mother in choosing foods that growth is not disturbed. Attention form/mothers support against children include attention when children eat and attitudes of the parents in feeding. Accordingly, it is a barometer of interesting problems to be studied. Therefore, this study aims to determine the relationship of positive deviance Feeding Practices and nurture the nutritional status of children in families in Baru Village.

\section{Method}

The research design used in this study was a cross-sectional study. This study was conducted in April-August 2016 for Baru Village, Sarolangun, Jambi. Several considerations to choose the study location was the high number of poor and good nutritional status in infants compared with other villages. The sampling technique in this study was purposive, with the criteria that have been set. Research sample criteria were: 1) Toddlers 24-60 months of age residing in Baru Village, Sarolangun; 2) Toddlers 24-60 months of age come from poor families with poverty indicators are less than IDR 1,900,000 per month income. Based on the initial observation, we obtained 84 sample toddlers that met the study criteria and the respondent is the mother of a toddler. Data collected in the study include family income, nutritional status of children, Feeding Practices, and habits of parenting a toddler. Nutrition status data retrieval using a body length measuring tools (tape measure and microtoise) and measuring the weight (bathroom scales). Determination of the nutritional status was using indicators of Body Weight/Age, which refers to the 2010 standard of Republic Indonesia Ministry of Health. We categorized the nutritional status into 2, namely: 1) a good nutritional status, if $\mathrm{z}$ 
score $\geq-2$; and 2) underweight, if $\mathrm{z}$ score $\geq 3 \mathrm{~s}$ / d $\mathrm{z}$ score $<-2$.

Family characteristics, positive deviance data of Feeding Practices and parenting a toddler was taken by a questionnaire. Positive deviance questionnaire of Feeding Practices consists of 11 items of questions with measuring results were categorized into two, namely: 1) Good, if the total score $\geq$ respondents median $(10,00)$; and 2) Less good, if the total score of respondents $<$ median (10.00). Meanwhile, positive deviance questionnaire of toddler parenting consists of six items of questions with the measuring results were categorized into two, namely: 1) Good, if the total score $\geq$ respondents median (11.00) and 2) Less good, if the total score of respondents $<$ median (11.00).

The data collected was analyzed using univariate and bivariate (chi-square test) using SPSS software. The univariate analysis in this study aimed to obtain the frequency distribution of positive deviance variable, positive deviance of Feeding Practices, and parenting a toddler. Bivariate analysis aimed to analyze the relationship between a positive deviance of Feeding Practices and parenting a toddler with nutritional status of children in poor families. The bivariate analysis using chi-square test $2 \times 2$, for statistical significance calculation results with a significance limit of 0.05 . If the $\mathrm{p}$-value $<0.05$, meaning that there was a relationship between positive deviance Feeding Practices and nutritional status of infants in poor families. Meanwhile, if the p-value $>0.05$, meaning that there was no positive deviance parenting relationship with the nutritional status of children under five in poor families.

\section{Results and Discussion}

The results showed that the majority of mothers belonging to early adult age. Descriptively, the average age of mothers was 33 years old, with the youngest aged 20 and the oldest 51 years of age. Maternal education were mostly graduates from junior high school (SMP) $(50.0 \%)$, and there was still $1(1.2 \%)$ mother that didn't go to school. The mother's education was the main asset in supporting the family economy, the preparation of family meals, parenting and child care. Level of parent education greatly affected the life within the family, especially the mother's education level that had greater influence. This was because the mother has a role and greater responsibility in parenting practices and child and family care (Cesare, 2013). According to Madanijah (2003), the mother's education was one of the determinants of infant and child mortality due to maternal education level influence on health care, hygiene, and awareness of the health of children and families.

Incomewasalso dominantin determining the lifestyle of families and communities of the region. Family incomes in this study included income of fathers, mothers, children, and other family members living in one household. The results of this study indicated that family income was low (below minimum wage and Jambi) with an average income of IDR 1,139,944, - / month. Income was one of the elements that can affect nutritional status. Reyes et al. (2004) study showed that the lack of household income will limit the ability of parents to care for children properly. This can be compounded by the number of children in the family.

Most of the mothers (86.9\%) were Housewife. Meanwhile, there were mothers who work as self-employed, farmers and civil servants. According to Merita (2013), the role of housewives in family nutrition improvement was essential. Few of the mother's roles in a family were as a nanny and a regulator of food consumption of the family members. Thus, the housewive-type mother will have more time in parenting and family dining setting.

The role of parents indicated in feeding behaviors. Behavior is something that can be established, acquired and learned through the process of learning by means of habituation, giving understanding, as well as a model. The behavior associated with health is called health behavior that shows a response of an individual (organism) to the stimuli or objects, associated with pain or illness, health care system, food / beverage and environment and classified as follows: 1) Health care behavior, 2) conduct searches or use of the system or health care facilities, 3) environmental health behavior. Feeding practices is a complex set of interactions between caregivers / parents and children under five, which involves the selection process, and the regulation of food 
consumption. Feeding behaviors parents can be interpreted also as an activity parents to meet the dietary, health and safety, helping to develop and maintain good eating behaviors, and promote a pleasant dining environment

Tabulated results in Table 1 showed that 77 mothers with positive deviances had good Feeding Practices and mostly good nutritional status was as much as 73 (94.7\%). The results of chi-square analysis showed that the positive deviance Feeding Practices significantly related to nutritional status of children in poor families in Baru Village, Sarolangun ( $p$-value $=0.001$ ). In line with the research results Jemide (2016), which concludes that there was a relationship between feeding practices with nutritional status of children in Nigeria. Similarly, studies in Ghana, which concluded that a good Feeding Practices in children was one of the factors that affect nutrition status in children under five in Ghana (Saaka, 2015; Amugsi, 2014).

The state of nutritional health depends on the level of nutrients consumption found in everyday foods. The consumption level is determined by the quality of the dish. If the composition of the dishes meets the body's needs, both in terms of quantity and quality, then the body will get nutrition health conditions as well as possible, so-called adequate consumption. Conversely consumption of poor quality and quantity will give health conditions of malnutrition or deficit (Rahim, 2014). Thus, in this case role of a mother in providing adequate and quality dishes especially to her child is necessary.

In this study, we found that poor families with good nutrition status, in child feeding practices utilize fish caught by family as the animal protein consumed in addition to tempe and tofu. This study found that most mothers have a positive deviance where they had good Feeding Practices (91.7\%). This was indicated by the habit of mothers who wash their hands when about feeding a child and toddler early accustom to consume local fruits. Moreover, because most mothers were housewives so mothers have more time to accompany children to eat. Mothers can create a fun atmosphere when children eat with their own way. If the child does not want to eat, she can persuade the children to spend their food. Therefore, it is also supported premises mother to child

Table 1. Cross Tabulation of Positive Deviance of Feeding Practices with Toddlers Nutritional Status on Poor Families

\begin{tabular}{|c|c|c|c|c|c|c|c|c|}
\hline \multirow{3}{*}{ No. } & \multirow{3}{*}{$\begin{array}{l}\text { Positive } \\
\text { Deviance } \\
\text { Feeding } \\
\text { Practices }\end{array}$} & \multicolumn{4}{|c|}{ Toddlers Nutritional Status } & \multirow{2}{*}{\multicolumn{2}{|c|}{ Number }} & \multirow{3}{*}{ P-Value } \\
\hline & & \multicolumn{2}{|c|}{ Underweight } & \multicolumn{2}{|c|}{ Normal } & & & \\
\hline & & $\mathrm{n}$ & $\%$ & $\mathrm{n}$ & $\%$ & $\mathrm{n}$ & $\%$ & \\
\hline 1 & Less Good & 4 & 57.1 & 3 & 42.9 & 7 & 100 & \\
\hline 2 & Good & 4 & 5.2 & 73 & 94,7 & 77 & 100 & 0,001 \\
\hline Total & & 8 & 9.5 & 76 & 90.5 & 84 & 100 & \\
\hline
\end{tabular}

Source : Primary Data

Table 2. Cross Tabulation of Positive Deviance of Carring Habits with Toddlers Nutritional Status on Poor Families

\begin{tabular}{|c|c|c|c|c|c|c|c|c|}
\hline \multirow{3}{*}{ No. } & \multirow{3}{*}{$\begin{array}{c}\text { Positive Deviance Carring } \\
\text { Practices }\end{array}$} & \multicolumn{4}{|c|}{ Toddlers Nutritional Status } & \multirow{2}{*}{\multicolumn{2}{|c|}{ Number }} & \multirow{3}{*}{ P-Value } \\
\hline & & \multicolumn{2}{|c|}{ Underweight } & \multicolumn{2}{|c|}{ Normal } & & & \\
\hline & & $\mathrm{n}$ & $\%$ & $\mathrm{n}$ & $\%$ & $\mathrm{n}$ & $\%$ & \\
\hline 1 & Less Good & 4 & 33.3 & 8 & 66.7 & 12 & 100 & \\
\hline 2 & Good & 4 & 5.6 & 68 & 94.4 & 72 & 100 & 0,013 \\
\hline Total & & 8 & 9.5 & 76 & 90.5 & 84 & 100 & \\
\hline
\end{tabular}

Source : Primary Data 
upbringing.

Cross tabulated results in Table 2 that of 72 mothers with positive deviances good Carring Practices mostly good nutritional status was as much as 68 (94.4\%) infants. Chi-square analysis showed that the positive deviance toddler Carring Practices significantly related to nutritional status of children in poor families in Baru Village, Sarolangun ( $\mathrm{p}$-value $=$ 0.013 ). These results were consistent with research Rapar (2014), which concluded there was a relationship between parenting mother with infant nutritional status in Puskesmas Ranotana Wanea Weru District of Manado.

Yulia (2010), also found that eating parenting is related positively and significantly with the nutritional status of children under five by the index Body Weight/Age. This condition significantly better score parenting eat it will be better the nutritional status of children under five. To get the results those respondents who have parenting better eating there for women who do not work (61.8\%). Mothers who work outside the home have a more limited time to carry out household chores that affect parenting and children's health eating. Similarly, the results of research Anas (2013), found that there is the influence of parenting eat on the nutritional status of children under the age of 0-59 months. Toddlers who do not foster good pattern had the possibility of 27 times greater malnutrition than children who eat a good upbringing.

The results of this study, we found that most of the positive deviance Carring Practices of infants in poor families is classified as good (85.7\%). This was shown on the item questions on the questionnaire which always accompany the child when the mother was ill $77(85.7 \%)$ and mother always prepared food for children (88.1\%). The basic needs of children divided into three namely. Parenting is to educate, guide and nurture children, taking care of food, drinks, clothing, hygiene. According to Lubis (2008), the mother as the central figure and is essential to implement life, especially in infants. Children still need the guidance of a mother in choosing foods that growth is not disturbed. Attention form / support mothers against children include attention when children eat and attitudes of the parents in feeding.
According to our study, mothers are expected to a supply good parenting style meal so that toddlers have a good meal intake and ultimately will have a good nutritional status.

\section{Conclusion}

Toddlers from poor families mostly had good nutritional status $(90.5 \%)$. This is supported by the positive deviance of behavior that is quite good at Feeding Practices such as washing hands before eating and the consumption of fruits early on, as well as the positive deviance on parenting toddlers as always accompany the sick child and prepare food for children. There is a significant correlation between positive deviance eating habits and nurture the nutritional status of children. Therefore, the effort required from the Department of Health Sarolangun to optimize nutrition improvement program through public behavior, especially about feeding and Carring Practices.

\section{Acknowledgments}

Acknowledgments to Ministries of research, technology, and higher education which has been submitted to provide the opportunity for researchers to get grants to faculty research skim starter in 2016, so this research can be planned and implemented well. Thanks also to Head of Baru Village, village midwives, Posyandu Cadres that are helping the process of implementation of the research as well as mothers of infants who have been willing respondent.

\section{References}

Amugsi, DA et al. 2014. Influence of childcare practices on nutritional status of Ghanaian children: a regression analysis of the Ghana Demographic and Health Surveys. BMJ Open, 4 (11): 53-65

Ali, Sadiq Mohammad. 2006. Socioeconomic, Psychosocial, Behavioral, and Psychological Determinants of BMI Among Young Women: Differing Patterns for Underweight and Overweight / Obesity. Eur J Public Health,16 (3): $324-330$

Anas, UK. 2013. Characteristics Influence of the Family and Parenting Toddlers on Mother's Nutritional Status Married Early in Puskesmas Keude Geureubak Banda Alam sub-district of East Aceh district. [Essay]. Faculty of Health Sciences University of North Sumatra, Medan.

Andriani Elisa P, Sofwan I. 2012. Determinants 
of Nutritional Status of Primary School Students. Jurnal KEMAS, 7 (2): 122-126

Basit A, et al. 2012. Risk Factors for Under-Nutrition among Children Aged One to Five Years in Udupi Taluk of Karnataka, India: a case control study. Australasian Medical Journal 5 (3): 163-167.

Bolles, K., et al. 2012. Ti Foyer (Hearth) CommunityBased Nutrition Activities Informed by the Positive Deviance Approach in Leogane, Haiti: A programmatic description. food and Nutrition Bulletin, 23 (4): 11-17.

Cesare MD, Sabates R, Keith M. Lewin.2013. A Double Prevention: How Can Education Affect Maternal Mental Maternal Health, Child Health and Child Cognitive Development. Longitudinal and Life Course Studies 4 (3).

[CORE] Child Survival Collaborations and Resources Group. 2000. positive Deviance \& Health, An Approach Behavior Change andHearth. Translated by PCI-Indonesia. Jakarta

Dearden, KA, et al. 2002. Work Outside the Home is the Primary Barrier to Exclusive Breastfeeding in Rural Vietnam: Insights from Mothers Who Breastfed and Worked Exclusively. Food and Nutrition Bulletin, 23 (4), 101-108.

Jemide, JO., Et al. 2016. Association of Maternal Nutrition and Child Feeding Practices Knowledge with Nutritional Status of Children in Calabar South Local Government Area, Cross River State, Nigeria. International Journal of Home Science, 2 (1): 293-298

Khomsan, A., 2014. Access Food, Hygiene, Sanitation, and Coping Strategies Households in Slum Areas. Minutes of Agricultural and Environmental Policy. 1 (2): 59-66

Kurniasih D, Hilmansyah H, Astuti MP, Imam S. 2010. Health and BugarBerkat Balanced Nutrition.Jakarta: Gramedia.

Lutter et al. 2011. Undernutrition, Poor Feeding Practices, and Low Coverage of Key Nutrition Intervention. Pediatrics 128 (6): e1418-e1427

Leavy, B. 2011. Leading Adaptive Change by Harnessing the Power of Positive Deviance. Strategy and Leadership 39 (2): 18-27

Lubis, R. 2008. Relationship with Parenting Mother Infant Nutritional Status in Puskesmas Pantai Cermin District of Tanjung Pura Langkat 2008. Thesis. USU

Mackintosh, U., Marsh, DR, \& Schroeder, DG 2002. Sustained Positive Deviant Child Care Practices and Their Effects on Child Growth in Vietnam. Food \& Nutrition Bulletin 23 (4):

\section{$16-25$}

Madanijah. 2003. Educational Model “GI-PSIHEALTHY” for Mothers and their Impact on Maternal Behavior, Learning Environment, Food Consumption and Nutritional Status of Young Children. Dissertation. Bogor (ID): Graduate, Bogor Agricultural University.

Mamhidira, G. 2006. Underweight, Weight Loss and Related Risk Factors Among Older Adults in Sheltered Housing: A Swedish FollowUp Study. The Journal of Nutrition, Health \& Aging, 10 (4): 255-262

Mashal et al. 2008. Factors Associated with the Health and Nutritional Status of Children Under 5 Years of Age in Afghanistan: Family Behavior Related to Women and the Past Experience of War-Related Hardships. BMC Public Health 8: 301

Merita. 2013. Impact of Nutrition Education Nutrition Behavior Against Women \& Service Quality IHC. Thesis.Bogor: IPB

Mosquera PA, et al. 2012. Primary Health Care Contribution to Improve Health Outcomes in Bogota-Colombia: a longitudinal ecological analysis. BMC Family Practice 13:84

Nursalam. 2005. Nursing care of infants and children (for nurses and midwives). Issue1.Jakarta: Salemba Medika

Ogunba BO. 2006. Maternal Feeding Practices Behavioral and Under-Five Nutrition: Implication for Child Development and Care. Journal of Applied Sciences Research 2 (12): 1132-1136

Parvanta, CF Thomas, KK, and Zaman, KS 2007. Changing Behavior Nutrition in Bangladesh: Successful Adaptation of New Theories and Anthropological methods. Ecology of Food and Nutrition, 46(3-4): 221-244

Pascale, RT, Sternin, J., \& Sternin, M. (2010). The Power of Positive Deviance: How Unlikely Innovators Solve the World's toughest Problems. Boston: Harvard Business Press.

Pryer, JA, Rogers, S., \& Rahman, A. 2004. The Epidemiology of Good Nutritional Status Among Children from a Population with a High Prevalence of Malnutrition. Public Health Nutrition, 7 (2): 311-317

Rahim, FK. 2014. Risk Factors Underweight. Age 7-59 Months Toddler. Jurnal KEMAS, 9 (2) : 115-121

Rapar, VL et al. 2014. Relationship of Parenting Mothers with Nutritional Status of Children in the Region of Sub-District Health Centers Weru Ranotana Wanea Manado City :1-7.

Rayhan I, Khan SH. 2006. Factor causing malnutrition among under-five children in 
Bangladesh. Pakistan Journal of Nutrition 5 (6) : 558-562

Reyes, Hortensia. 2004. The Family as Determinants of Stunting in Children Living in Conditions of Extreme Poverty: a case control study, BMC Public Health 4 (57).

Saaka, M., Larbi, A. \& Hoeschle-zeledón, I., 2015. Nutritional Factors Contributing to Positive Deviance in the Growth of Children. Jacobs Journal of Food and Nutrition,2 (2), pp.1-12

Sripaipan, T., et al. 2002. Effect of an Integrated Nutrition Program on Child Morbidity Due to Respiratory Infection and Diarrhea in Northern Vietnam. Food and Nutrition Bulletin, 23(4), 70-77.

The Positive Deviance Initiative. 2010. Basic Field Guide to the Positive Deviance Approach. Tufts University

Turnip, OS., Arita, EY., Siregar, M., 2014. Revenues Relations, Infectious Diseases and Nutrition
Knowledge Genesis Capital with less in Toddlers in Regional Health Center West Glugur 2014. Journal of PublicHealth,3 (2), pp.25-37.

World Bank. 2006. Repositioning Nutrition as Central to Development, a strategy for LargeScaleAction.Washington DC (US): World Bank

Yulia, C., Sunarti, E., Roosita, K. 2010. Parenting and Healthy Eating Toddler on the Family Women Tea Pickers in PTPN VIII Canning. Info Food and Nutrition, 19(2).

Setijowati, N., Wirawan, NN, Apriyanto, D. 2012. Differences in Parenting Eating at Various Levels of IHC to Level of Energy and Protein Consumption in the District of Moyo Hulu Toddler Sumbawa Regency of West Nusa Tenggara. Thesis. Faculty of Medicine, University of Brawijaya, Malang 